\title{
COMPARISON OF LIFE CYCLE ASSESSMENT TOOLS IN CEMENT PRODUCTION
}

\author{
B.D. Olagunju ${ }^{1 *} \&$ O.A. Olanrewaju ${ }^{1}$
}

\section{ARTICLE INFO}

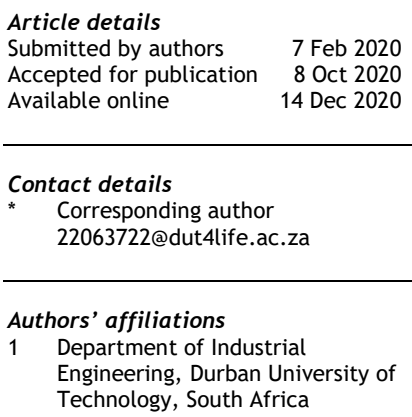

ORCID® identifiers

B.D. Olagunju

https: //orcid.org/0000-0002-7336-5073

O.A. Olanrewaju

https: / /orcid.org/0000-0002-3099-9295

DOI

http://dx.doi.org/10.7166/31-4-2317

\section{ABSTRACT}

The cement industry is known to be the largest consumer of energy and natural resources. Globally, an average of a ton of cement is needed by every individual each year. Cement, being the major constituent of concrete, is the most manufactured and most consumed product, and its environmental impact continuously increases; this in turn causes climate change and global warming. This has stimulated the quest to understand the environmental implications of the cement industry through life cycle assessment. The need to review life cycle assessment (LCA) software that is available for cement production is thus germane, as the desired output to be obtained in an LCA largely depends on the choice of the software package to be used. Of the 45 LCA software tools reviewed, we report on a comparison of four suitable and prominent software packages $-\mathrm{GaBi}$, OpenLCA, SimaPro, and Umberto - for the cement industry. From our analysis, SimaPro emerged as the best software tool for the cement industry, based on the required standards. However, every user knows what is required in a tool; thus this paper helps to link the desired output to a particular software tool.

\section{OPSOMMING}

Die sement industrie is bekend as die grootste verbruiker van energie en natuurlike hulpbronne. 'n Ton sement word wêreldwyd deur elke individu elke jaar gebruik. Sement, as die hoof bestanddeel van beton, is die produk wat die meeste geproduseer word en die meeste verbuik word. Die omgewingsimpak daarvan neem kontinu toe, wat weer lei tot klimaatsverandering en globale verhitting. Die implikasies wat die sement industrie vir die omgewing inhou word dus ondersoek deur middel van lewensiklus assessering. Daar is dus ' $n$ behoefte om lewensiklus assessering sagteware te ondersoek, omdat die resultaat van so 'n assessering grootliks beïnvloed word deur die spesifieke sagteware pakket. Vyf-en-veertig sagteware pakkette is evalueer en vier gepaste en prominente voorbeelde word vergelyk in hierdie artikel. Hulle is $\mathrm{GaBi}$, OpenLCA, SimaPro en Umberto. SimaPro is aangewys as die gepaste sagteware pakket vir die sement industrie aan die hand van die vereiste standaarde. Elke gebruiker weet egter wat vereis word van 'n werkstuk en hierdie artikel help om die verlangde uitset aan 'n spesifieke sagteware werkstuk te koppel.

\section{INTRODUCTION}

With changes in the global landscape resulting from continuous urbanisation, the demand to expand the built environment is growing; but this is not without its own environmental impact. To meet this increased demand, the production of concrete has grown, with cement being the major constituent. The pace of its production surpasses that of all other materials, and of population growth. Meeting these demands without placing too much stress on the environment is a great problem. Understanding its environmental implications thus becomes imperative [1-4]. Several environmental and sustainability impacts faced by the cement industry occur across the entire production process. These include greenhouse gas emissions, high energy consumption, and resource depletion, which are encountered in the production of cement (Figure 1) and in its entire life cycle [5]. 
The cost of energy and material in cement production is high [6-12]. Ali and Allwood assessed the energy consumption, and estimated that cement consumes $12-15$ per cent of total industrial energy [13, 14]. About eighteen years ago, the total energy consumed by the production process of cement was estimated to be about 70-80 per cent [16]. More recently, however, it was estimated to use about 40-50 per cent of the total energy with respect to plant efficiency [6], with clinker production being the most energy-consuming of all the production stages [15]. There is thus a continuous need to improve the energy efficiency and environmental impact of the cement industry.

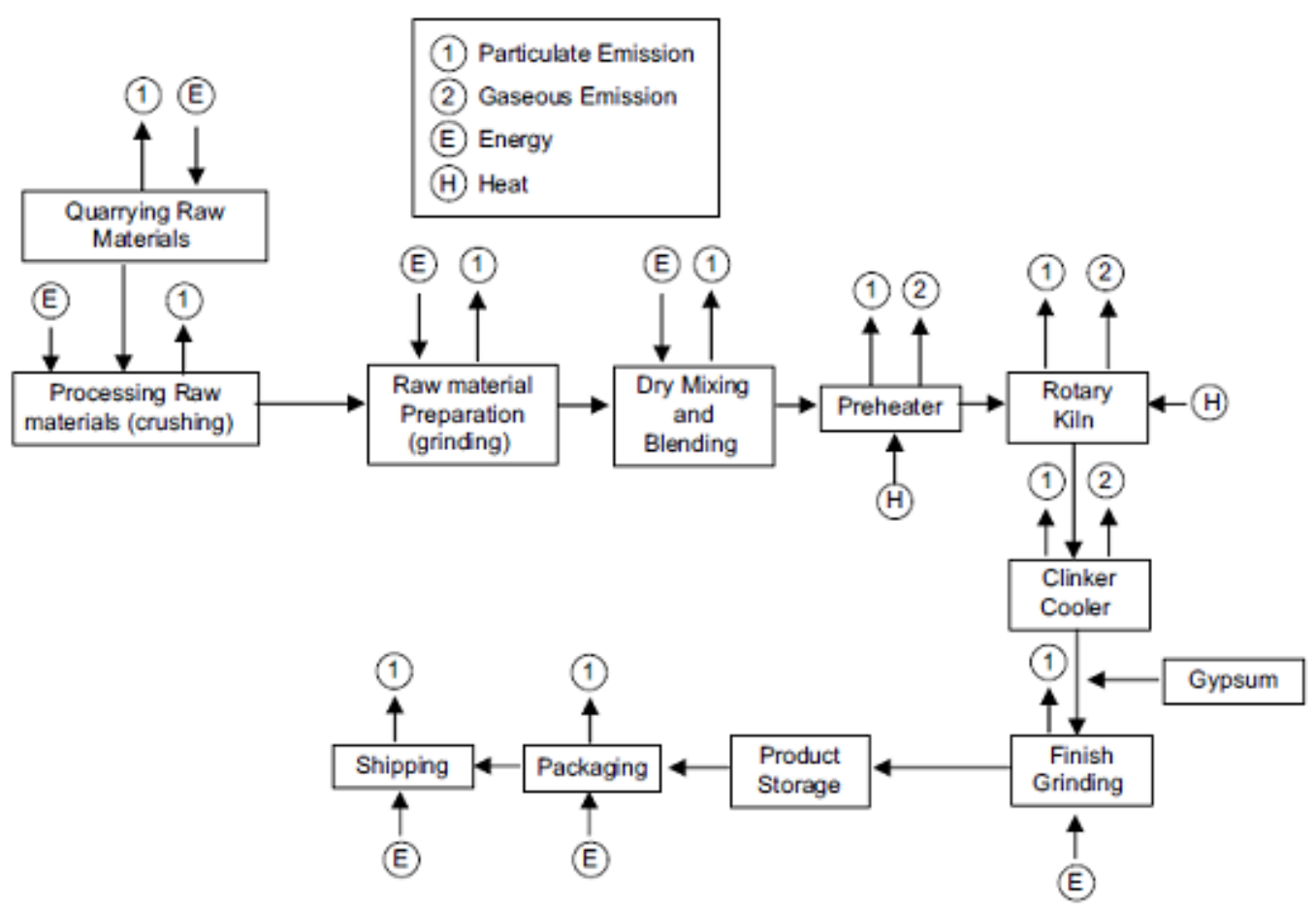

Figure 1: Process flow of cement production floor showing energy consumption and emissions [12]

Attempts to safeguard the environment and to improve socio-economic and environment issues have been of constant interest in the last few decades. Society is aware that some products and services have negative effects on the value of the environment and on resources, to some degree. These effects may occur throughout the production processes of products or services (as the case may be) [17]. Although environmental impact is essentially dependent on its origin, it is fast becoming a criterion for the development of socioeconomic policies. Statistical analysis reveals that global warming potential (GWP), which is one of the prevalent parameters for evaluating the environmental impact of industrial processes, follows a regular pattern, which explains why the cement industry is a global concern because of its environmental impact [18-20]. A thorough analytical approach is required to evaluate the environmental impact of the whole cement production process, and of its use in construction [21]. One such prominent approach in the literature is known as 'life cycle assessment' (LCA).

Life cycle assessment is an effective approach to understanding and improving the environmental impact of cement production, seeing that it reveals the potential threats encountered during this process. This makes it a vital tool for cement producers [12].

\section{LIFE CYCLE ASSESSMENT (LCA)}

Life cycle assessment (LCA) is a system-oriented approach to assessing the environmental impacts of a product or process, by examining all the stages of a production process, from the extraction of raw material ('cradle'), to cement production ('gate'), to cement application, to its useful life and to its end-of-life or recycling ('grave'). This gives rise to another name for the approach: 'cradle to gate' or 'cradle to grave'. It was developed more than three decades ago, primarily to support decision-making [5] [17]. The effective application of LCA is a function of the goal of any study. Thus there is flexibility in the implementation of 
LCA from one study to another, depending on its defined goal [22] [23]. In 1997, the International Organization for Standardization (ISO) established the framework for evaluating the possible environmental impacts of a product, process, and/or service to meet the needs of many industries around the world. The framework is known as the ISO 14000 series; its standards include a requirement to carry out an LCA, and provide guidance on procedures and methods. However, to prevent variations among these ISO standards and to enhance their readability, two new international standards for LCA were published in 2006: ISO 14040 and ISO 14044, respectively defined as principles and framework requirements and as guidelines without requirements [23], [5]. The environmental management documentation includes further definitions, clarifications, and detailed technical descriptions and applications of LCA that replace the initial standards [24]. The four stages of LCA recommended by the ISO are: ISO 14041 - goal and scope definition and life cycle inventory analysis (LCI); ISO 14042 - life cycle impact assessment (LCIA); and ISO 14043 - Interpretation. They are shown in Figure 2 [5, 25].

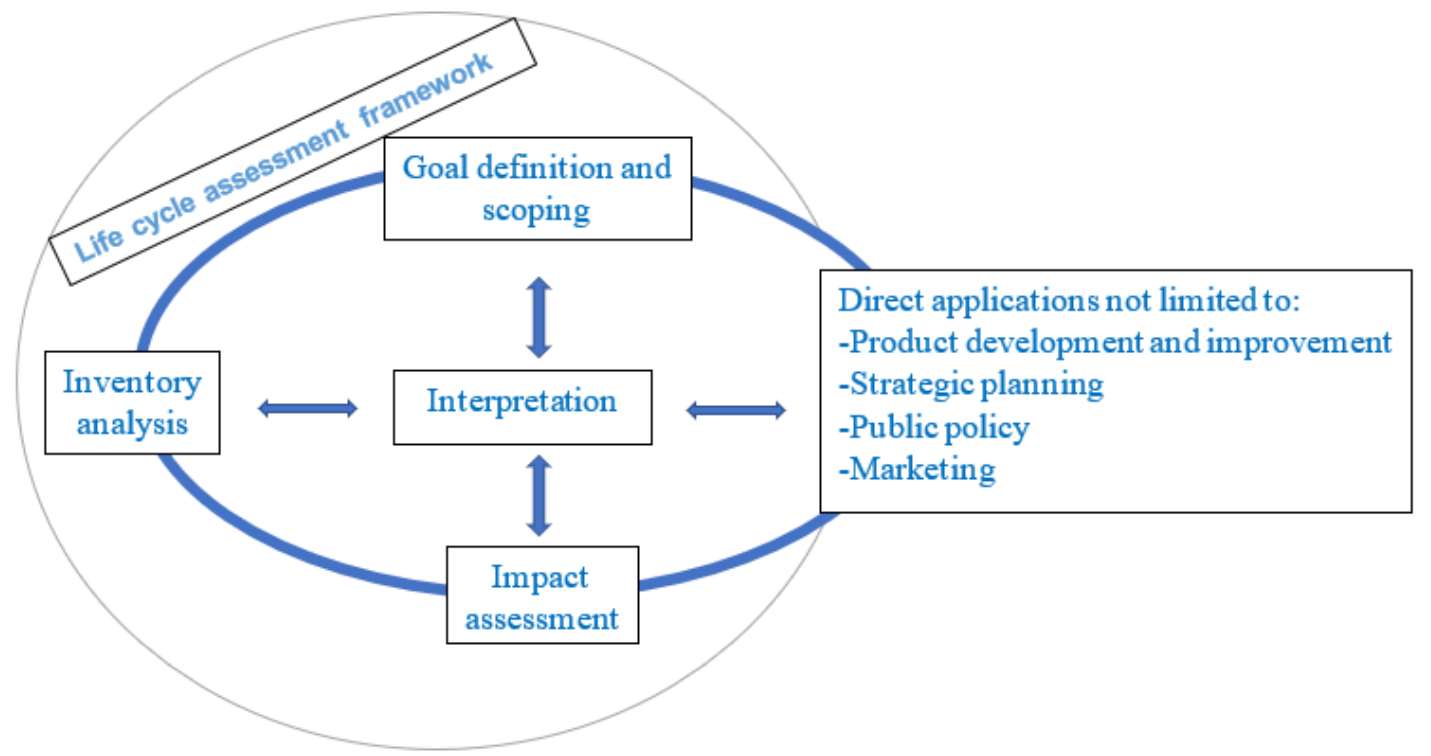

Figure 2: Adapted LCA phases and applications [22]

\subsection{Goal and scope definition}

It is of utmost importance first to define the goal clearly when carrying out a life cycle assessment of a process or product. The purpose of the assessment should include what the result will be used for, and who will use the results (the intended audience). In a cement industry, the main focus is on assessing the environmental impact, based on data on the unit production of cement [7], while the scope will be the raw material acquisition, processing, and product manufacturing stages [12]. The scope of an LCA study defines the extent of the assessment. The following must be clearly explained in the scope definition: the system to be studied and its function, the functional unit, the system boundaries, the types of impact and the impact assessment method, data quality requirements, assumptions, and limitations [26] [27]. 'System boundaries' refers to what in the system is to be taken into consideration or left out. 'Functional unit' is also a fundamental factor in a study: it clearly explains the measurement used in a system. The results of the LCA will primarily be translated into the terms of the functional unit; for example: if the functional unit is in tons of cement, the results would be in tons as well [5].

\subsection{Life cycle Inventory (LCI)}

Life cycle Inventory (LCI) analysis (ISO 14041) has to do with compiling input and output inventory data that is not only consistent with the product being assessed, but also involves several environmental areas [27]. For a cement industry, the cradle-to-gate inventory involves all the raw materials and the essential requirements at every phase of production; while a cradle-to-grave inventory requires the above-mentioned inventory, but extended to include the useful life of the product and its disposal or recycling. Tools and software are available to assist in the collection of inventory data that corresponds to the background system [5], A good example of one such tool is the Ecolnvent database, which was recently considered one of the best databases for construction materials [28, 29]. 


\section{4) Interpretation}

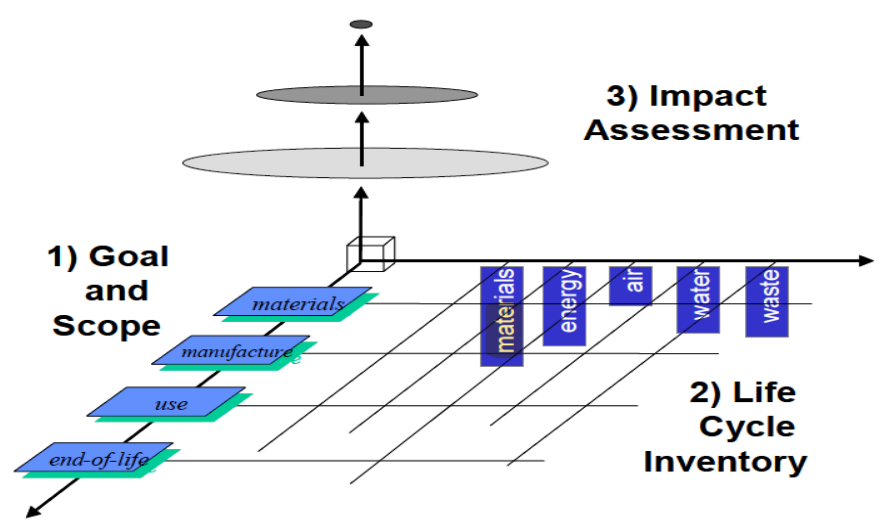

Figure 3: Graphical illustration of the four stages of the LCA's interplay with basic resources [5]

There are no grounds for assessing the potential environmental effects, or even room for improvement, without an LCI. The quality of the data will be evident throughout all of the LCA stages from this point [17].

\subsection{Life cycle impact assessment (LCIA)}

A life cycle impact assessment (ISO 14042) is a multiple-issue tool that is used to evaluate potential environmental impacts that are in line with the environmental resources (inputs and outputs) identified in the life cycle inventory. This assessment addresses several environmental issues, such as energy, climate change, and water pollution, thus allowing for a comprehensive evaluation of the impacts of the system [5]. This is an attempt to establish the connection between a product and its potential environmental impacts [17]. The impact assessment is divided into classification, characterisation, and valuation [30], as seen in Table 1 below. The evaluated impacts are classified into three broad groups: human health, ecological health, and resource depletion, in order to have a proper description of the analysed effects of a product [27]. 'Characterisation' is the summation of the data that is within the impact groups by using equivalency factors [30]. Basically, it is a quantifiable phase that evaluates the comparative influence of the several inputs or outputs by grouping them [31]. The important aim of characterisation is to pattern each model after scientific knowledge as much as possible [26]. The valuation can be either qualitatively or quantitatively carried out by professional groups, or by the evaluation of the environmental loading profiles respectively [32].

Table 1: LCA structure as proposed by the Society of Environmental Toxicology and Chemistry (SETAC) (adapted by [30, 33])

\begin{tabular}{ll} 
Analysis & Goal definition and scope \\
& Inventory analysis \\
\hline Assessment & Impact assessment, which is divided into: \\
& $\bullet \quad \begin{array}{l}\text { Classification } \\
\text { - }\end{array}$ \\
& $\bullet \quad$ Valuation \\
Interpretation & Improvement analysis
\end{tabular}

\subsection{Interpretation (ISO 14043)}

Interpretation, which is the last stage, is an efficient method used to evaluate, compute, and categorise the results from the information provided by the life cycle inventory $(\mathrm{LCl})$ and the life cycle impact assessment (LCIA), and to relate them effectively. In this phase, the expert identifies important environmental pointers (e.g. energy, $\mathrm{CO}_{2}$ gases), the important influences on these pointers, and important unit processes in the cycle. A good example of what the expert does in a situation in which the result shows a large value - for example, global warming potential - is to trace the assessment back to the $\mathrm{LCl}$ in order to identify the particular unit process that produces the output that results in that 'hotspot'. The interpretation requires that the sensitivity of the results be examined, a scenario analysis be performed, the quality of the data be reviewed, and the result be fitted to the goal of the study [5]. Below are the two 
objectives of life cycle interpretation as outlined by the International Organization for Standardization (ISO):

- To clarify limitations, evaluate results, draw conclusions, present a lucid result and proffer recommendations on the basis of the outcomes of the stages of the LCA [17].

- To readily offer a logical, comprehensive and reliable results presentation of the LCA study, with regard to the stated goal and scope [23].

LCA software is thus important, as it largely determines the outcome of the LCA, which in turn is a tool to support the taking of decisions. The ability to follow up different outputs reveals the quality of a software package. This study reviewed several software tools for evaluating LCA, based on the established standards, by different authors and organisations. The databases associated with LCA change over time, along with the applications, and some are more suitable for particular production process than others. As a result, the methodologies proposed in this paper are as set out below.

- $\quad$ Review selected tools based on the information and recommendations provided by ISO environmental management and standards, as well as the literature.

- $\quad$ Select the widely used software tools that are suitable for a cement industry and analyse them.

The key method in this paper for evaluating tools is to review the literature that has made use of these tools, alongside information from the web pages/manuals of the software packages, and compare them in the light of the cement industry and the required standards.

\section{REQUIREMENTS OF LCA SOFTWARE TOOLS}

Assessing environmental impact is a complex process [34]. Therefore a wide variety of software tools is available to carry out this assessment effectively with one variation or another; but they are not without their similarities. They vary in their elemental features such as database and the methodologies applied. Ormazabal [34] stated that, when environmental impact is to be assessed, some of the critical parameters required of the software tools are user-friendliness, and the volume, quality, accuracy, and relevance of the available data. Below the features required for a good software tool are discussed.

\subsection{Database}

The information in the database needs to be transparent and of a high quality (characteristics of data that relate to their ability to satisfy the stated requirements). High-quality data contains not only the source and age of the data, but also its composition (where the data is generated from, the different contributions of the literature, and the number of companies that contributed) in its documentation. Also, the data should be able to update automatically as often as possible, possibly connected to a website. The data should be stored and managed in a clearly structured database or library that is separate from the modelling interface. A very convenient database for most users is one that is similar to MS Office and in which data can be modified without interfering with the main workspace. A good software product should also have sensitivity analysis.

\subsection{User-friendliness}

Of fundamental importance is a self-explanatory and structured user interface. A user should feel comfortable working with the software owing to its flexibility. It should require little time to master the tool. It should be simple and concise in presenting results, showing the best options. Different versions, and a free demo version giving a quick overview of the functionality and features of the software, should be available in a software tool. Software ergonomics is of great importance in software design, as this allow for continuous improvement, the elimination of malfunctions, and an increased user-friendliness index. A website with detailed information should be provided for an LCA software tool. Information for beginners as well as experts should be readily available, and a website with the necessary information should be available. Other features that would allow users to assess results easily and leave room for other evaluations are of great importance. Most often in linear equation systems, a definition of the quantity of input and output will be sufficient, although scripts might be essential for some processes.

\subsection{Structures}

High-quality software needs to have a hierarchical structure to ensure transparency and modelling comfort. Results should be traceable in the calculation module by the user so that mistakes can be traced. Reports from the modelling should be linear and analytical. A process chain that uses graphical modelling is 
convenient for the user. The software should contain features such as the assumptions and methodological solutions (assessment methods). Also, one should be able to model different outputs, have clear results, and have a choice of starting point; and the compatibility of the software with other applications should be assured.

\subsection{Uncertainty analysis}

This is a common analytical technique in life cycle assessment tools. It refers primarily to the uncertainty of measured parameters (e.g., the inaccuracy of emissions measured or of normalisation data) and of the differences between sources (e.g., different emissions from similar processes) and objects [35]. A simple parameter variation through statistical modelling methods such Monte Carlo simulation would cater to these potential distortions. These procedures are suitable for evaluating the effect of the uncertain parameters in the model output, and thus the accuracy of the overall model. A good LCA tool, therefore, is one that incorporates uncertainty and variability analyses.

\subsection{Impact assessment methods}

The definition of an LCA is from the application of a set of documented characteristic features that comply with the recommendation of ISO 14040 standard. The two prevalent and internationally recognised methods for LCA are the CML 2001 method [36] and Eco-Indicator 99 [37]. They are guides to the operation of ISO standards, and follow different approaches: $\mathrm{CML}$ is a problem-oriented method, while Eco-Indicator 99 is a damage-oriented method. When CML is used in isolation, the software will still require another way to interpret results. Thus a good software tool should provide at least these two methods. Also, a good impact assessment method should be able to give room to choose among different available methods, choose a result collection style, and compare scenarios with various outputs.

\subsection{Presentation}

The user will as a matter of necessity present results to different groups of people. Therefore, a good software tool should have a good presentation module. A good process chain can be well represented using a Sankey diagram - a type of flow diagram that shows all the primary energy flows in a system. It is a pictorial representation in which the width of the arrows is linearly proportional to the flow rate. A visualisation of the energy report, the material flow at both regional or national levels, and cost breakdowns are included in its operation. Sankey diagrams highlight the major flows in a system and help to locate the significant contributions to a flow. Also, results should be presented in a structured hierarchy and allow diagrams to be created. The hardware requirements should also be adequate.

In general, the main reason for using LCA is to calculate the environmental influence, environmental hot spots (processes and substances that have significant environmental impacts), and the potential impact of a product, and to use the results to make decisions. In evaluating the life cycles of products, the output is often the major focus. The major question is then: How can a quantity of cement that is produced yield the minimum environmental impact? A good software tool should be able to answer this question. Ormazabal and Young [5, 34] argued that the most suitable software for LCA in the cement world are those that have the following characteristics:

- The availability of a quality database

- $\quad$ Compliance with the ISO 14040 series of LCA standards

- It can be used to define a full life cycle assessment methodology, from goal and definition to $\mathrm{LCl}$, to LCIA, and to interpretation [5, 34].

\section{$4 \quad$ LCA SOFTWARE TOOLS}

There are more than 45 LCA software tools in the market, and some are more suitable for cement production than others. A study was carried out to assess the accessibility and importance of these tools, and to suggest the most useful ones. The absence of specific tools from the list should not be taken as a negative recommendation.

The study considered different sources, which included the websites of the software producers, the literature, software reviews, and LCA resources. However, these tools present a wide range of skills for specific audiences - LCA practitioners, product designers, environmental managers, process engineers, etc. - and also the type of LCA performed, whether a full LCA or a quick LCA. The major difference between the two types is the size of the database that is required [36, 38-45]. Table 2 below lists all the tools that were considered in this study. 
Table 2: List of software tools

\begin{tabular}{|c|c|c|c|c|c|c|c|c|c|}
\hline $\mathrm{S} / \mathrm{N}$ & Name & Vendor/ Developer & Tool & Database & $\begin{array}{l}\text { ISO } 14040 \\
\text { guidelines }\end{array}$ & (DQA) & LCIA & $\begin{array}{l}\text { Statistical } \\
\text { analysis }\end{array}$ & Comments \\
\hline 1 & AIST-LCA v4 & $\begin{array}{l}\text { National Institute of } \\
\text { Advanced Industrial } \\
\text { Science and Technology } \\
\text { (AIST), Japan }\end{array}$ & $\mathrm{Y}$ & $\mathrm{Y}$ & $\mathrm{Y}$ & $\mathrm{N}$ & $\mathrm{N}$ & $\mathrm{N}$ & $\begin{array}{l}\text { www.aistriss.jp/main } \\
\text { General }\end{array}$ \\
\hline 2 & Athena & $\begin{array}{l}\text { Athena Sustainable } \\
\text { Materials Institute, } \\
\text { Canada }\end{array}$ & $\mathrm{Y}$ & $\mathrm{N}$ & $\mathrm{N}$ & $\mathrm{N}$ & $Y$ & $\mathrm{~N}$ & $\begin{array}{l}\text { www. athenasmi.org. More focused on building \& } \\
\text { construction }\end{array}$ \\
\hline 3 & BEES 4.0 & $\begin{array}{l}\text { National Institute of } \\
\text { Standards } \\
\text { and Technology, USA }\end{array}$ & $\mathrm{Y}$ & $\mathrm{Y}$ & $\mathrm{N}$ & $\mathrm{N}$ & $\mathrm{Y}$ & $\mathrm{N}$ & $\begin{array}{l}\text { www. nist.gov/el/economics/ BEESSoftware.cfm } \\
\text { More focused on building \& construction }\end{array}$ \\
\hline 4 & Boustead & Boustead Consulting, UK & $\mathrm{Y}$ & $\mathrm{Y}$ & $\mathrm{Y}$ & $\mathrm{N}$ & $\mathrm{N}$ & $\mathrm{N}$ & $\begin{array}{l}\text { www. boustead-consulting.co.uk } \\
\text { Decrease in relevance, standard LCIA } \\
\text { parameters }\end{array}$ \\
\hline 5 & Build-it & $\begin{array}{l}\text { IKP, University of } \\
\text { Stuttgart }\end{array}$ & $\mathrm{Y}$ & $\mathrm{Y}$ & $\mathrm{N}$ & $\mathrm{N}$ & $Y$ & $\mathrm{~N}$ & \\
\hline 6 & CMLCA & $\begin{array}{l}\text { Leiden University, } \\
\text { Institute of } \\
\text { Environmental Sciences } \\
(\mathrm{CML}), \text { Holland }\end{array}$ & $\mathrm{Y}$ & $\mathrm{Y}$ & $\mathrm{Y}$ & $\mathrm{N}$ & $\mathrm{Y}$ & $\mathrm{N}$ & $\begin{array}{l}\text { www.cml.leiden.edu/ } \\
\text { software/ }\end{array}$ \\
\hline 7 & $\begin{array}{l}\text { Design } \\
\text { System } 4.0\end{array}$ & $\begin{array}{l}\text { Assess Ecostrategy } \\
\text { Scandinavia AB, } \\
\text { Göteborg, Sweden }\end{array}$ & $\mathrm{Y}$ & $\mathrm{N}$ & $\mathrm{N}$ & $\mathrm{N}$ & $\mathrm{Y}$ & $\mathrm{N}$ & $\begin{array}{l}\text { http: / / www.ecosmes. net/cm/viewDoc?id=6564\&l=EN } \\
\text { General but limited }\end{array}$ \\
\hline 8 & $\mathrm{E}^{3}$ Database & $\begin{array}{l}\text { Ludwig-Bölkow- } \\
\text { Systemtechnik GmbH, } \\
\text { Germany }\end{array}$ & $\mathrm{Y}$ & $\mathrm{Y}$ & $X$ & $X$ & $x$ & $\mathrm{X}$ & www.e3database.com \\
\hline 9 & $\begin{array}{l}\text { Earthsther } \\
\text { turbo }\end{array}$ & GreenDelta GmbH & $\mathrm{Y}$ & $\mathrm{Y}$ & $\mathrm{N}$ & $\mathrm{N}$ & $\mathrm{N}$ & $\mathrm{N}$ & www.greendelta.com \\
\hline 10 & $\begin{array}{l}\text { ECO-BAT } \\
\text { V4.0 }\end{array}$ & $\begin{array}{l}\text { Haute Ecole d'Ingénierie } \\
\text { et de Gestion du Canton } \\
\text { de Vaud, } \\
\text { Switzerland }\end{array}$ & $\mathrm{Y}$ & $\mathrm{N}$ & $\mathrm{N}$ & $\mathrm{N}$ & $\mathrm{Y}$ & $\mathrm{N}$ & www.eco-bat.ch \\
\hline 12 & Ecolab & Nordic Port AB, Sweden & $\mathrm{Y}$ & $\mathrm{Y}$ & $\mathrm{N}$ & $\mathrm{N}$ & $Y$ & $\mathrm{~N}$ & www.ecolab.com \\
\hline 13 & EcoManager & Franklin Associates, USA & $\mathrm{Y}$ & $\mathrm{Y}$ & $\mathrm{N}$ & $\mathrm{N}$ & $N$ & $N$ & $\begin{array}{l}\text { https://www.kaercher.com/ca/services/professional-LCI } \\
\text { tool } \\
\text { US/UK data }\end{array}$ \\
\hline 14 & EcoAssessor & PIRA, UK & $\mathrm{Y}$ & $\mathrm{N}$ & $\mathrm{N}$ & $\mathrm{N}$ & $\mathrm{Y}$ & $\mathrm{N}$ & Only literature data \\
\hline 15 & Eco-Quantum & Netherlands & $\mathrm{Y}$ & $\mathrm{N}$ & $\mathrm{N}$ & $\mathrm{N}$ & $\mathrm{N}$ & $\mathrm{N}$ & $\begin{array}{l}\text { www. ivam. uva. } \mathrm{nl} / \text { ?id=2\&L=1 } \\
\text { Specific to building }\end{array}$ \\
\hline
\end{tabular}




\begin{tabular}{|c|c|c|c|c|c|c|c|c|c|}
\hline $\mathrm{S} / \mathrm{N}$ & Name & Vendor/ Developer & Tool & Database & $\begin{array}{l}\text { ISO } 14040 \\
\text { guidelines }\end{array}$ & (DQA) & LCIA & $\begin{array}{l}\text { Statistical } \\
\text { analysis }\end{array}$ & Comments \\
\hline 16 & EcoScan 3.0 & $\begin{array}{l}\text { TNO Industrial } \\
\text { Technology, Eindhoven, } \\
\text { Netherlands }\end{array}$ & $\mathrm{Y}$ & $\mathrm{N}$ & $\mathrm{N}$ & $\mathrm{N}$ & $\mathrm{Y}$ & $\mathrm{N}$ & $\begin{array}{l}\text { www.ecosmes.net/cm/viewDoc?id=6564\&l=en } \\
\text { General but limited }\end{array}$ \\
\hline 17 & $\begin{array}{l}\text { EDIP LCV } \\
\text { Tool }\end{array}$ & $\begin{array}{l}\text { Institute for Product } \\
\text { Dev't, Denmark }\end{array}$ & $\mathrm{Y}$ & $Y$ & $Y$ & $\mathrm{Y}$ & $Y$ & $\mathrm{Y}$ & $\begin{array}{l}\text { http: / / lca.jrc.ec.europ a.eu } \\
\text { General but limited }\end{array}$ \\
\hline 18 & ELCD & EU & $\mathrm{N}$ & $\mathrm{Y}$ & $\mathrm{N}$ & $\mathrm{N}$ & $N$ & $N$ & $\begin{array}{l}\text { Http: / / lca.jrc.ec.europa.eu } \\
\text { General but limited }\end{array}$ \\
\hline 19 & ENVEST & $\begin{array}{l}\text { BRE, United Kingdom } \\
\text { Sponsored by UK } \\
\text { Department of Energy, } \\
\text { Transport \& Regions }\end{array}$ & $\mathrm{Y}$ & $\mathrm{N}$ & $\mathrm{N}$ & $\mathrm{N}$ & $\mathrm{N}$ & $\mathrm{N}$ & $\begin{array}{l}\text { http://envest2.bre.co.uk/ } \\
\text { Used with BRE environmental profiles database listed } \\
\text { below } \\
\text { Uses eco-points based on equivalencies to compare } \\
\text { building design options. Specific to building }\end{array}$ \\
\hline 20 & EQUER & France & $Y$ & $Y$ & $\mathrm{~N}$ & $\mathrm{~N}$ & $\mathrm{Y}$ & $\mathrm{N}$ & Specific to building www.izuba.fr/logiciel/equer \\
\hline 21 & Gabi & $\begin{array}{l}\text { IKP Uni. Stuttgart/PE, } \\
\text { Germany }\end{array}$ & $\mathrm{Y}$ & $\mathrm{Y}$ & $\mathrm{Y}$ & $\mathrm{Y}$ & $\mathrm{Y}$ & & $\begin{array}{l}\text { General but very suitable for building and assemblies } \\
\text { construction } \\
\text { www.gabi-software.com/ }\end{array}$ \\
\hline 22 & GEMIS & Oeko Institute, Germany & $\mathrm{Y}$ & $\mathrm{Y}$ & $\mathrm{N}$ & $\mathrm{Y}$ & $\mathrm{N}$ & $\mathrm{N}$ & $\begin{array}{l}\text { www.gemis.de } \\
\text { Emission modelling software } \\
\text { (general) }\end{array}$ \\
\hline 23 & Idemat & TU Delft, Netherlands & $\mathrm{Y}$ & $\mathrm{Y}$ & $\mathrm{N}$ & $\mathrm{N}$ & $\mathrm{Y}$ & $\mathrm{N}$ & $\begin{array}{l}\text { Www.ecocostsvalue.com/EVR/model/theory/5- } \\
\text { Idemat.html } \\
\text { Used to select \& compare individual } \\
\text { materials or processes - designer-oriented }\end{array}$ \\
\hline 24 & JEMAI-LCA & JEMAI, Japan & $\mathrm{Y}$ & $\mathrm{Y}$ & $\mathrm{Y}$ & $\mathrm{Y}$ & $\mathrm{Y}$ & & $\begin{array}{l}\text { www.jemai.or.jp/english/index.cfm } \\
\text { No comparisons between products, Japan-specific, only } \\
\text { available in Japanese }\end{array}$ \\
\hline 25 & $\frac{\mathrm{KCL}-\mathrm{ECO}}{\underline{3.01}}$ & $\begin{array}{l}\text { Oy Kesuslaboratorio- } \\
\text { Centrallaboratorium Ab } \\
\text { (KLC), Espoo, Finland }\end{array}$ & $\mathrm{Y}$ & $\mathrm{N}$ & $\mathrm{N}$ & $\mathrm{N}$ & $\mathrm{Y}$ & $\mathrm{N}$ & $\begin{array}{l}\text { www.ecosmes.net/cm/viewDoc?id=6564\&l=EN } \\
\text { General }\end{array}$ \\
\hline 26 & LEGEP & $\begin{array}{l}\text { LEGEP Software } \mathrm{GmbH} \text {, } \\
\text { Germany }\end{array}$ & $\mathrm{Y}$ & $\mathrm{Y}$ & $\mathrm{Y}$ & $\mathrm{Y}$ & $\mathrm{Y}$ & $\mathrm{N}$ & $\begin{array}{l}\text { www.legep.de/?lang=en } \\
\text { Focuses on design, construction, quantity surveying, and } \\
\text { evaluation of new or existing buildings }\end{array}$ \\
\hline 27 & LCAdvantage & Battelle/DOE, USA & $\mathrm{Y}$ & $\mathrm{Y}$ & $\mathrm{Y}$ & $\mathrm{N}$ & $\mathrm{Y}$ & $\mathrm{N}$ & Weak database, US only \\
\hline 28 & LCAid $^{\text {TM }}$ & $\begin{array}{l}\text { DPWS Environmental } \\
\text { Services, NSW, } \\
\text { Australia }\end{array}$ & $\mathrm{Y}$ & $\mathrm{Y}$ & $\mathrm{N}$ & $\mathrm{N}$ & $\mathrm{Y}$ & $\mathrm{N}$ & $\begin{array}{l}\text { Www.irbnet.de/daten/iconda/CIB10092 } \\
\text { Limited to EI 95, waste, waste \& energy. } \\
\text { Mostly Australian data Can import 3D CAD drawing for } \\
\text { building } \\
\text { assessment }\end{array}$ \\
\hline 29 & LCAiT & $\begin{array}{l}\text { Chalmers Ind. (CIT), } \\
\text { Sweden }\end{array}$ & $\mathrm{Y}$ & $\mathrm{Y}$ & $Y$ & $\mathrm{~N}$ & $Y$ & $\mathrm{~N}$ & $\begin{array}{l}\text { Www.ecosmes.net } / \mathrm{cm} / \text { viewDoc?id=6564\&l=EN } \\
\text { Measuring environmental performance of buildings }\end{array}$ \\
\hline
\end{tabular}




\begin{tabular}{|c|c|c|c|c|c|c|c|c|c|}
\hline $\mathrm{S} / \mathrm{N}$ & Name & Vendor/ Developer & Tool & Database & $\begin{array}{l}\text { ISO } 14040 \\
\text { guidelines }\end{array}$ & (DQA) & LCIA & $\begin{array}{l}\text { Statistical } \\
\text { analysis }\end{array}$ & Comments \\
\hline 30 & $\begin{array}{l}\text { Life Cycle } \\
\text { Explorer }\end{array}$ & United States & $\mathrm{Y}$ & $\mathrm{N}$ & $\mathrm{N}$ & $\mathrm{Y}$ & $\mathrm{Y}$ & $\mathrm{Y}$ & Prototype used to assess window design options \\
\hline 31 & NIRE LCA & NIRE, Japan & $\mathrm{Y}$ & $\mathrm{Y}$ & $\mathrm{N}$ & $\mathrm{N}$ & $\mathrm{N}$ & $\mathrm{N}$ & \\
\hline 32 & $\begin{array}{l}\text { OpenLCA } \\
1.10 .1\end{array}$ & GreenDelta GmbH & $\mathrm{Y}$ & $\mathrm{N}$ & $\mathrm{N}$ & $\mathrm{Y}$ & $\mathrm{N}$ & $\mathrm{Y}$ & $\begin{array}{l}\text { Www.openlca.org/ } \\
\text { General }\end{array}$ \\
\hline 33 & PEMS & Pira International, UK & $\mathrm{Y}$ & $\mathrm{Y}$ & $\mathrm{Y}$ & $\mathrm{Y}$ & $\mathrm{Y}$ & $\mathrm{Y}$ & Limited; Public data only. \\
\hline 34 & $\underline{\text { PTLaser }^{\mathrm{TM}}}$ & $\begin{array}{l}\text { Sylvatica, North Berwick, } \\
\text { Maine, USA }\end{array}$ & $\mathrm{Y}$ & $\mathrm{N}$ & $\mathrm{N}$ & $\mathrm{N}$ & $\mathrm{N}$ & $\mathrm{N}$ & $\begin{array}{l}\text { Www.ecosmes.net/cm/viewDoc?id=6564\&l=EN } \\
\text { Limited }\end{array}$ \\
\hline 35 & REGIS & $\begin{array}{l}\text { Sinum AG- } \\
\text { EcoPerformance } \\
\text { Systems }\end{array}$ & $\mathrm{Y}$ & $\mathrm{Y}$ & $\mathrm{Y}$ & $\mathrm{N}$ & $\mathrm{Y}$ & $\mathrm{N}$ & $\begin{array}{l}\text { Www.sinum.com/ } \\
\text { General, but limited to linear equations }\end{array}$ \\
\hline 36 & REPAQ & Franklin Associates, USA & $Y$ & $Y$ & $\mathrm{~N}$ & $\mathrm{~N}$ & $\mathrm{~N}$ & $\mathrm{~N}$ & $\begin{array}{l}\mathrm{LCI} \text { tool } \\
\text { US/UK data }\end{array}$ \\
\hline 37 & SABENTO & $\begin{array}{l}\text { Ifu Hamburg GmbH, } \\
\text { Germany }\end{array}$ & $Y$ & $\mathrm{Y}$ & Y & $\mathrm{Y}$ & $\mathrm{Y}$ & $\mathrm{Y}$ & $\begin{array}{l}\text { Www.sabento.com } \\
\text { Data from literature, strong materials } \\
\text { Flow accounting (chemical) }\end{array}$ \\
\hline 38 & SimaPro & $\begin{array}{l}\text { PRé-Consultants } \\
\text { Netherlands }\end{array}$ & $Y$ & $Y$ & $\mathrm{Y}$ & $Y$ & $\mathrm{Y}$ & $\mathrm{Y}$ & $\begin{array}{l}\text { www.pre-sustainability. } \\
\text { com/ } \\
\text { General; efficient for all }\end{array}$ \\
\hline 39 & Spine & CPM, Sweden & $\mathrm{Y}$ & $Y$ & $\mathrm{~N}$ & $\mathrm{~N}$ & $\mathrm{Y}$ & $\mathrm{N}$ & $\begin{array}{l}\text { Http://195.215.251.229/Dotnetnuke/ } \\
\text { Data tool, no calculation, just storage and facilitation of } \\
\text { data collection }\end{array}$ \\
\hline 40 & SULCA & $\begin{array}{l}\text { VTT Technical Research } \\
\text { Centre of Finland }\end{array}$ & $Y$ & $\mathrm{~N}$ & $\mathrm{~N}$ & $\mathrm{~N}$ & $\mathrm{~N}$ & $\mathrm{~N}$ & $\begin{array}{l}\text { https://www.simulationstore.com/sulca } \\
\text { General }\end{array}$ \\
\hline 41 & TEAM & $\begin{array}{l}\text { Ecobilan/ } \\
\text { Ecobalance/Price } \\
\text { WaterhouseCoopers PW, } \\
\text { Europe/USA }\end{array}$ & $Y$ & $Y$ & $Y$ & $\mathrm{Y}$ & $\mathrm{Y}$ & $Y$ & $\begin{array}{l}\text { Www.ecobilan.pwc.fr/en/boiteaoutils/tem.jhtml } \\
\text { Limited }\end{array}$ \\
\hline 42 & TESPI & ENEA, Italy & $Y$ & $\mathrm{~N}$ & $\mathrm{~N}$ & $\mathrm{~N}$ & $\mathrm{Y}$ & $\mathrm{N}$ & $\begin{array}{l}\text { www.elca.enea.it/ } \\
\text { General but limited }\end{array}$ \\
\hline 43 & Umberto & Ifu Hamburg GMBH & $\mathrm{Y}$ & $Y$ & $\mathrm{Y}$ & $\mathrm{Y}$ & $\mathrm{Y}$ & $\mathrm{Y}$ & $\begin{array}{l}\text { www.umberto.de/en } \\
\text { Data from literature, strong materials } \\
\text { flow accounting. General }\end{array}$ \\
\hline 44 & USES-LCA & $\begin{array}{l}\text { Netherlands Center For } \\
\text { Environmental Modeling }\end{array}$ & $\mathrm{Y}$ & $\mathrm{N}$ & $\mathrm{N}$ & $\mathrm{N}$ & $\mathrm{N}$ & $\mathrm{N}$ & $\begin{array}{l}\text { www.cemnl.eu/useslca. } \mathrm{Html} \text {. } \\
\text { Terrestrial, freshwater, and marine ecosystems }\end{array}$ \\
\hline 45 & US NREL & USA & $\mathrm{N}$ & $Y$ & $\mathrm{~N}$ & $\mathrm{Y}$ & $\mathrm{N}$ & $\mathrm{N}$ & $\begin{array}{l}\text { www.nrel.gov/lci } \\
\text { General and limited }\end{array}$ \\
\hline
\end{tabular}

ISO - complies with the ISO 14040 standards on LCA

DQA - data quality assessment evaluation

Impacts - impact assessment method

Stats - features of simple parameter variations (Monte Carlo) 
Several articles, papers, and books were reviewed; the four software tools that have stood the test of time as being suitable for the cement industry are discussed in Table 3.

Table 3: Four most suitable tools for LCA in the cement industry.

\begin{tabular}{|c|c|c|c|c|c|c|c|c|c|}
\hline $\mathrm{S} / \mathrm{N}$ & Name & $\begin{array}{l}\text { Vendor/ } \\
\text { Developer }\end{array}$ & Tool & Database & $\begin{array}{l}\text { ISO } 14040 \\
\text { guidelines }\end{array}$ & (DQA) & LCIA & $\begin{array}{l}\text { Statistical } \\
\text { analysis }\end{array}$ & Comments \\
\hline 1 & $\mathrm{GaBi}$ & $\begin{array}{l}\text { IKP Uni. } \\
\text { Stuttgart/PE, } \\
\text { Germany }\end{array}$ & $\checkmark$ & $\checkmark$ & $\checkmark$ & $\checkmark$ & $\checkmark$ & $\checkmark$ & $\begin{array}{l}\text { www.gabi- } \\
\text { software.com General } \\
\text { but very suitable for } \\
\text { building and } \\
\text { assemblies } \\
\text { construction }\end{array}$ \\
\hline 2 & $\begin{array}{l}\text { OpenLCA } \\
1.10 .1\end{array}$ & $\begin{array}{l}\text { GreenDelta } \\
\text { GmbH }\end{array}$ & $\checkmark$ & $x$ & $x$ & $\checkmark$ & $x$ & $\checkmark$ & $\begin{array}{l}\text { www.openlca.org/ } \\
\text { Generic }\end{array}$ \\
\hline 3 & SimaPro & $\begin{array}{l}\text { PRé- } \\
\text { Consultants, } \\
\text { Netherlands }\end{array}$ & $\checkmark$ & $\checkmark$ & $\checkmark$ & $\checkmark$ & $\checkmark$ & $\checkmark$ & $\begin{array}{l}\text { www.pre- } \\
\text { sustainability. } \\
\text { com/ } \\
\text { Generic; efficient for } \\
\text { all } \\
\end{array}$ \\
\hline 4 & Umberto & $\begin{array}{l}\text { Ifu Hamburg } \\
\text { GMBH }\end{array}$ & $\checkmark$ & $\checkmark$ & $\checkmark$ & $\checkmark$ & $\checkmark$ & $\checkmark$ & $\begin{array}{l}\text { www.umberto.de/en } \\
\text { Data from literature, } \\
\text { strong for materials, } \\
\text { flow accounting } \\
\text { Generic }\end{array}$ \\
\hline
\end{tabular}

The following are characteristic features that are similar in the four software packages:

- These tools present results using Sankey diagrams; this is a good tool for visualising the influence of each process through to the entire impact via the width of the diagram.

- They include an uncertainty analysis that monitors potential distortion in measurement through Monte Carlo analysis.

- $\quad$ They give room for the creation of processes that allow easy calculation.

- They leave room for comparisons between product and processes.

- Results are usually reported in the form that is often communicated to organisations, associations, or third parties.

- $\quad$ They leave room for data quality checks.

- They also allow results to be exported both in graphical form and in text-based, editable formats (such as MS Word or MS Excel, and other programs).

- $\quad$ They leave room for the minimum requirements, which are the LCI and the LCIA.

- The results obtained from the evaluations will be different, based on the data provided and the defined goals [5, 38, 46-50].

\subsection{OpenLCA}

This is a freeware package that allows users to evaluate all the stages of LCA with ease. The term 'freeware' refers to any software that can be downloaded from the internet and used for free (which makes it costeffective). However, it is often a closed source with no stipulated software rights, so that the publisher can retain the copyright of the source codes. This software was developed in 2006 by GreenDelta, with the support of PE International (the developers of $\mathrm{GaBi}$ ), PRé Consultants (the creators of SimaPro), and UNEP (the United Nations Environment Programme) [49]. Some of its features are:

- OpenLCA does not contain a database, but works with OpenLCA Nexus (an online repository for LCA data that includes primarily the Ecoinvent, ELCD, and GaBi databases). OpenLCA was initially designed to evaluate the environmental impact of products and processes, but it can now evaluate LCC [49]. Some of the features of this software are:

- The databases in OpenLCA Nexus do not contain LCIA methods, which need to be imported and created manually in each database in OpenLCA Nexus to carry out life cycle impact assessment.

- It also allows the graphical presentation of the processes that have the largest impacts, and lists all the impacts.

- It does not comply with the ISO 14040 guidelines for LCA in its operation.

- It provides more visual results, even between different products [49].

\subsection{Umberto}

This software was developed by Ifu Hamburg over 25 years ago. Some characteristics features include: 
- It is less user friendly than SimaPro and GaBi and it doesn't bring significant innovation when compared with the other software [34].

- $\quad$ it is more suitable for flow accounting and processes that involve strong material

- $\quad$ Provide the minimum requirements, which are the LCA and LCIA.

- Following installation, Ecoinvent $\mathrm{LCl}$ database and/or the $\mathrm{GaBi} \mathrm{LCl}$ databases are extracted in the software

- It considers ISO 14040 guidelines for LCA in its operation [50].

\subsection{SimaPro}

SimaPro is one of the leading software packages, and has been found useful in the industry and in academia for more than 25 years in over 80 countries. It was developed by PRé Consultants, and is widely used around the worldm with continuous improvement in its functionality from one version to the next. The latest version is SimaPro 9.0. The following are some of its characteristic features:

- $\quad$ SimaPro comes with the Ecoinvent v3.6 database, covering over 10,000 processes.

- It comes with a large number of standard impact assessment methods.

- $\quad$ SimaPro allows you to create completely new methods or to delete impact categories/methods.

- It complies with the ISO 14040 guidelines for LCA in its operation.

- This tool allows users to customise the database, impact assessment methods, and inputs.

- $\quad$ SimaPro allows the graphical illustration of processes that produce high impacts.

- It allows comparison between products with different results and different values.

- It lists all impacts. Thus it gives robust yet sufficient result.

- SimaPro's interpretation stage is designed in the form of a list that covers the significant issues mentioned in the ISO 14044 standard.

- Currently, SimaPro can be run in UK English, US English, Dutch, Danish, French, German, Italian, Portuguese, Spanish, Swedish, and Japanese.

- $\quad$ Both full and quick evaluations can be performed using this software.

- $\quad$ SimaPro also weighs environmental impacts based on additional outputs.

- It allows a pictorial view of an outcome immediately that the parameters are changed.

- Results are often presented in the form of reports, because they will be communicated to stakeholders.

- It allows recycling and allocation scenarios calculation.

- The software provides Europe-specific LCIA methods [5, 38, 46, 47].

\subsection{GaBi}

GaBi was developed by PE Product Engineering GmBH and IKP in Germany. This tool has been used for 25 years by 10,000 users in 19 countries, and serves more than 2,000 companies. It was developed to allow the user a full LCA evaluation as well as life cycle costing (LCC). Its characteristic features are:

- Gabi allows user to customise the database, the impact assessment methods, and inputs with utmost transparency.

- It is available in English, Japanese, and German, and is used globally [51].

- It offers the most instinctive graphical interface for displays.

- $\quad \mathrm{GaBi}$ allows comparison of the results of different parameters.

- $\mathrm{GaBi}$ is a dynamic software that gives you a pictorial view of an outcome immediately that the parameters are changed.

- It follows the ISO 14040 guidelines for LCA in its operation.

- $\mathrm{GaBi}$ is designed with a text editor that allows editing and of and graphs, and automatically modifies them when the inventory changes.

- $\quad \mathrm{GaBi}$ allows the user to carry out non-liner process modelling.

- It allows both recycling loops and allocation calculations.

- The databases available in this software are in line with ISO TR 14049, and are hyperlinked to individual datasets using HTML files. This allows data to be traced to back to raw materials [51].

- $\quad$ Both full and quick evaluations can be performed using this software.

- $\mathrm{GaBi}$ is a complex tool that is designed for different users and LCA practitioners [51].

- It is highly focused on the automotive and electronics industries, and its major users are in these industries. It also has a suite known as the GaBi Life Cycle Engineering Suite. 
Table 4: Summary of some characteristics of selected tools for LCA evaluation

\begin{tabular}{|c|c|c|c|c|}
\hline AREA & GABI & OPENLCA & SIMAPRO & UMBERTO \\
\hline Database & YES & NO & YES & YES \\
\hline $\begin{array}{l}\text { ISO } 14040 \\
\text { guidelines }\end{array}$ & YES & NO & YES & YES \\
\hline (DQA) & YES & YES & YES & YES \\
\hline $\mathrm{LClA}$ & YES & NO & YES & YES \\
\hline $\begin{array}{l}\text { Statistical } \\
\text { analysis }\end{array}$ & YES & YES & YES & YES \\
\hline $\begin{array}{l}\text { Reports of } \\
\text { results }\end{array}$ & $\begin{array}{l}\text { Self-editor for } \\
\text { reports } \\
\text { Exports to } \\
\text { Word/Excel }\end{array}$ & $\begin{array}{l}\text { Graphical } \\
\text { Report presentation, } \\
\text { custom tables } \\
\text { Exports to Word/ } \\
\text { Excel }\end{array}$ & $\begin{array}{l}\text { Graphical } \\
\text { Report presentation with list } \\
\text { of impacts } \\
\text { Exports to Word/ Excel }\end{array}$ & $\begin{array}{l}\text { Graphical } \\
\text { Report } \\
\text { presentation } \\
\text { Exports to } \\
\text { Word/ Excel }\end{array}$ \\
\hline Communication & $\begin{array}{l}\text { Yes. GaBi } \\
\text { users/database } \\
\text { users }\end{array}$ & $\begin{array}{l}\text { Yes, between } \\
\text { SimaPro users and } \\
\text { EcoSpold and other } \\
\text { tools such as CAD }\end{array}$ & Yes EcoSpold ILCD & YES \\
\hline $\begin{array}{l}\text { Graphical } \\
\text { interface }\end{array}$ & $\begin{array}{l}\text { Intuitive flow- } \\
\text { path, Sankey } \\
\text { diagram }\end{array}$ & $\begin{array}{l}\text { Flow-path, Sankey } \\
\text { diagram }\end{array}$ & Flow-path, Sankey diagram & Sankey diagram \\
\hline Database & $\begin{array}{l}\text { Gabi datasets, } \\
\text { Ecoinvent, US LCA } \\
\text { (NREL) }\end{array}$ & No & $\begin{array}{l}\text { Ecoinvent, US input/output, } \\
\text { US LCI, Dutch input/output, } \\
\text { Swiss input/output, LCA food, } \\
\text { industry data, Japanese } \\
\text { input/output, IVAM }\end{array}$ & $\begin{array}{l}\text { Gabi database, } \\
\text { Ecoinvent }\end{array}$ \\
\hline $\begin{array}{l}\text { Comparison of } \\
\text { results }\end{array}$ & $\begin{array}{l}\text { Yes, product and } \\
\text { process }\end{array}$ & Yes & Yes, product and process & Yes \\
\hline
\end{tabular}

\section{CONCLUSION}

The environmental impact of any process or product is a critical issue that requires a careful selection of suitable software for an accurate and comprehensive evaluation, based on the goal definitions and the databases that were input. With the global concern caused by resource depletion, high energy consumption, and greenhouse gas emission from the production of cement, this study carefully examined the suitability of prominent software packages such as OpenLCA, SimaPro, GaBi, and Umberto for their life cycle assessments. OpenLCA, a freeware package, was found to be user-friendly and cost-effective. It is about 41 - 94 per cent as fast as SimaPro when calculating a large Ecoinvent unit process, but it cannot be used to analyse LCA for a cement industry because it does not consider the ISO14040 guidelines in its operation; and it does not come with a database and impact assessment method. An impact assessment method would have to be created manually for each imported database.

Of the three remaining software packages (SimaPro, GaBi, and Umberto), which have been in existence for over 25 years, Umberto is not as robust in its characteristic features as the others. It is not user-friendly, and does not necessarily offer sufficient innovations compared with SimaPro and $\mathrm{GaBi}$, even though they are of a similar price. $\mathrm{GaBi}$, which seems to be more robust in its characteristic features, is too complex to work with, and is focused more on the automobile industry than on the cement industry. SimaPro, which has robust characteristic features, complies with almost all the requirements of LCA software, with a wide range of databases that are suited to the cement industry. It is therefore strongly recommended as the most suitable LCA software for the cement industry. However, the choice of a software package is left to the LCA practitioner to make, based on the desired output. This paper serves as a guide to tailoring the user's desired outputs to a particular software package that would be very useful, based on the available database.

\section{REFERENCES}

[1] Lippiatt, B. \& Ahmad, S. 2004. Measuring the life cycle environmental and economic performance of concrete: The BEES approach. In Proceedings of the International Workshop on Sustainable Development and Concrete Technology.

[2] Van Oss, H.G. \& Padovani, A.C. 2002. Cement manufacture and the environment: Part I: Chemistry and technology. Journal of Industrial Ecology, 6(1), pp. 89-105.

[3] Van Oss, H.G. and Padovani, A.C. 2003. Cement manufacture and the environment: Part II: Environmental challenges and opportunities. Journal of Industrial Ecology, 7(1), pp. 93-126. 
[4] Masanet, E., Price, L., de la Rue du Can, S., Brown, R. 2005. Reducing greenhouse gas emissions from products manufactured in California. In Second annual climate change research conference, Sacramento, CA; September 14, 2005.

[5] Young, S.B., Turnbull, S. \& Russell, A. 2002. Substudy 6: What LCA can tell us about the cement industry.

[6] Summerbell, D.L., Khripko, D., Barlow, C. \& Hesselbach, J. 2017. Cost and carbon reductions from industrial demand-side management: Study of potential savings at a cement plant. Applied Energy, 197, pp. 100-113.

[7] Stafford, F.N., Raupp-Pereira, F., Labrincha, J.A. \& Hotza, D. 2016. Life cycle assessment of the production of cement: A Brazilian case study. Journal of Cleaner Production, 137, pp. 1293-1299.

[8] Kabir, G., Abubakar, A. \& El-Nafaty, U. 2010. Energy audit and conservation opportunities for pyroprocessing unit of a typical dry process cement plant. Energy, 35(3), pp. 1237-1243.

[9] Madlool, N., Saidur, R., Rahim, N.A., Islam, M.R. \& Hossian, M.S. 2012. An exergy analysis for cement industries: An overview. Renewable and Sustainable Energy Reviews, 16(1), pp. 921-932.

[10] Mirzakhani, M.A., Tahouni, N. \& Panjeshahi, M.H. 2017. Energy benchmarking of cement industry, based on process integration concepts. Energy, 130, pp. 382-391.

[11] Madlool, N.A., Saidur, R., Hossain, M.S. \& Rahim, N.A. 2011. A critical review on energy use and savings in the cement industries. Renewable and Sustainable Energy Reviews, 15(4), pp. 2042-2060.

[12] Huntzinger, D.N. \& Eatmon, T.D. 2009. A life cycle assessment of Portland cement manufacturing: Comparing the traditional process with alternative technologies. Journal of Cleaner Production, 17(7), pp. 668-675.

[13] Ali, M., Saidur, R. \& Hossain, M. 2011. A review on emission analysis in cement industries. Renewable and Sustainable Energy Reviews, 15(5), pp. 2252-2261.

[14] Allwood, J.M. \& Cullen, J.M. 2012. Sustainable materials: With both eyes open. Cambridge: UIT Cambridge.

[15] Barcelo, L., Kline, J., Walenta, G. \& Gartner, E. 2014. Cement and carbon emissions. Materials and Structures, 47(6), pp. 1055-1065.

[16] Worrell, E., Price, L., Martin, N., Hendriks, C. \& Ozawa Meida, L. 2001. Carbon dioxide emissions from the global cement industry. Annual Review of Energy and the Environment, 26(1), pp. 303-329.

[17] Ailleret, F. 2004. Comparison of energy systems using life cycle assessment. A special report of the World Energy Council. London: World Energy Council.

[18] Miccoli, S., Finucci, F. \& Murro, R. 2014. Criteria and procedures for regional environmental regeneration: A European strategic project. Applied Mechanics and Materials, 675-677, pp. 401-405.

[19] Miccoli, S., Finucci, F. \& Murro, R. 2014. Assessing project quality: A multidimensional approach. Advanced Materials Research, 1030-1032, pp. 2519-2522.

[20] Miccoli, S., Finucci, F. \& Murro, R. 2014. A monetary measure of inclusive goods: The concept of deliberative appraisal in the context of urban agriculture. Sustainability, 6(12), pp. 9007-9026.

[21] Gursel, A.P. 2014. Life cycle assessment of concrete: Decision-support tool and case study application. UC Berkeley.

[22] International Organization for Standardization (ISO). 1997. ISO 14040: Environmental management - Life cycle assessment - Principles and framework.

[23] International Organization for Standardization (ISO). 2006. Environmental management: Life cycle assessment: Principles and framework. ISO.

[24] You, S. \& Wang, X. 2019. On the carbon abatement potential and economic viability of biochar production systems: Cost-benefit and life cycle assessment. In Ok, Y., Tsang, D., Bolan, N. \& Novak, J. (eds), Biochar from biomass and waste: Fundamentals and applications. Cambridge: Elsevier, pp. 385-408.

[25] El Haggar, S.M. 2005. Rural and developing country solutions. in Agardy, F. \& Nemerow, N. (eds), Environmental solutions. Cambridge: Elsevier, pp. 313-400.

[26] Hoffman, L. \& Schmidt, A. 1997. Life cycle assessment: A guide to approaches, experiences and information sources. recurso electronic, EPA,

[27] Marinković, S. 2013. Eco-efficient concrete: 3. Life cycle assessment (LCA) aspects of concrete. Cambridge: Woodhead Publishing.

[28] Martínez-Rocamora, A., Solís-Guzmán, J. \& Marrero, M. 2016. LCA databases focused on construction materials: A review. Renewable and Sustainable Energy Reviews, 58, pp. 565-573.

[29] Stafford, F.N., Dias, A.C., Arroja, L., Labrincha, J.A. \& Hotza, D. 2016. Life cycle assessment of the production of Portland cement: A Southern Europe case study. Journal of Cleaner Production, 126, pp. 159-165.

[30] Andersson, K., Ohlsson, T. \& Olsson, P. 1994. Life cycle assessment (LCA) of food products and production systems. Trends in Food Science \& Technology, 5(5), pp. 134-138.

[31] Tansey, G., Worsley, T. \& Traill, B. 1995. The food system. Nature, 378(6552), pp. 102-102.

[32] Arvanitoyannis, I.S. 2008. Waste management for the food industries: 3 - ISO 14040: Life cycle assessment (LCA) - Principles and guidelines. Cambridge, MA: Elsevier Academic Press.

[33] Tibor, T. \& Feldman, I. 1997. Implementing ISO 14000: A practical, comprehensive guide to the ISO 14000 environmental management standards. New York: Irwin Professional Pub.

[34] Ormazabal, M., Jaca, C. \& Puga-Leal, R. 2014. Analysis and comparison of life cycle assessment and carbon footprint software. In Xu J., Cruz-Machado, V., Lev, B. \& Nickel S. (eds), Proceedings of the Eighth International Conference on Management Science and Engineering Management: Advances in Intelligent Systems and Computing, vol 281. Berlin, Heidelberg: Springer.

[35] Huijbregts, M. 2002. Uncertainty and variability in environmental life cycle assessment. The International Journal of Life Cycle Assessment, 7(3), pp. 173-173.

[36] Guinée, J., Heijungs, R., Huppes, G., Koning, A.D., Oers, L., Sleeswijk, A.W., Haes, U.D., Duin, R.V. \& Lindeijer, E. 2001. Life cycle assessment-An operational guide to the ISO Standards Ministry of Housing. Spatial Planning and the Environment (VROM), and Centre of Environmental Science, Leiden University (CML), The Netherlands. 
[37] Goedkoop, M., Effting, S. \& Collignon, M. 2000. The Eco-Indicator 99: Manual for designers: A damage oriented method for life cycle impact assessment. Amersfoort: PRé Consultants.

[38] Jonbrink, A.K., Wolf-Watz, C., Erixon, M., Olsson, P. \& Wallén, E. 2000. LCA software survey. Mölndal, Sweden: IVF Research Publication 00824.

[39] Janssen, M., Buckland, B. \& Peshos, Z. 1999. Stadium Australia energy use and the role of concrete. Concrete in Australia, Vol. 25, No. 1. Mar-May 1999. <http: //www.engaust.com.au/magazines/cia/0399coverstory.html>..

[40] NIST. BEES 2.0. Office of Applied Economics. National Institute of Standards and Technology. 2 May 2001. <http://www.bfrl.nist.gov/oae/software/bees.html>.

[41] Wilgenbush, B. 2000. LCA software - Internal report. Atlanta: Interface Research Corporation.

[42] De Caluwe, N. 1997. Ecotools manual - A comprehensive review of design for environment tools. In Design for the Environment Research Group, DFE/TR33, Manchester: Manchester Metropolitan University.

[43] IVAM. 1999. Eco-Quantum. 18 Jul 2001. Available online [Accessed 10 December 2020]: http://www.except.nl/overig/yale/sem5/sustainabledesign/Eco-Quantum2.pdf

[44] Ecosite. EcoSite software back information. 13 Aug 2001. Avialbel online: http://www.ecosite.co.uk/depart/backinfo/softconb.html

[45] Gloria, T. 2000. LCA software. Life cycle assessment links.

[46] Pré Consultants, B., SimaPro. URL: https://network. simapro. com/esuservices, 2016.

[47] Goedkoop, M., Leijting, J., Ponsioen, T., Meijer, E., Introduction to LCA with SimaPro. 5.2 ed. January 2016: SimaPro. 80.

[48] Thilo Kupfer, D.M.B., Colodel, C.M., Kokborg, M., Schöll, S., Rudolf, M., Thellier, L., Bos, U., Bosch, F., Gonzalez, M., Schuller, O., Hengstler, J., Stoffregen, A., Thyl-mann, D., GaBi Database \& Modelling Principles. thinkstep GaBi. February 2018: GaBi. 200.

[49] Ciroth, C.D.N., Lohse, T., Srocka, M., OpenLCA 1.9 Comprehensive User Manual. 1.9.0 ed. June 2019, Müllerstrasse 13513349 Berlin, Germany: GreenDelta GmbH. 127.

[50] ifu Hamberg GmbH. 2017. Umberto® LCA+(v10) User Manual. Available online: https://www.ifu.com/fileadmin/user_upload/umberto/Support/SupportDokumente/Umberto_LCAPlus_User_Manual_WEB.pdf

[51] Kreissig, J.I. 2001. Personal communication, April 2001. 